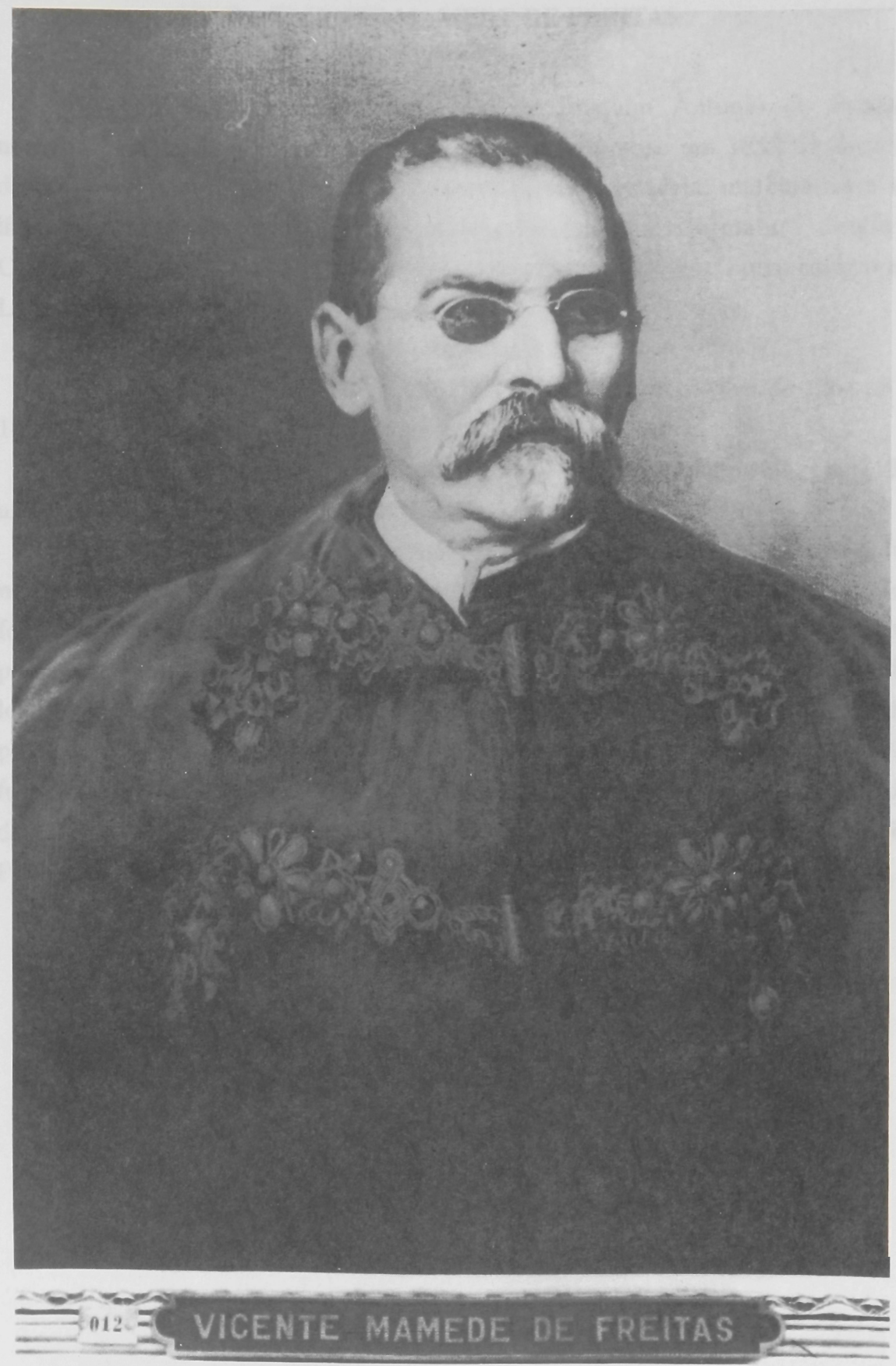





\section{Dr. VICENTE MAMEDE DE FREITAS}

(1904-1908)

Natural de São Paulo, filho de Joaquim Antonio de Freitas, matriculou-se no Curso Jurídico em 1851 e bacharelou-se em 1855. Dedicado, desde muito moço, ao magistério, lecionou filosofia, história, matemática e as línguas latina, francesa e inglesa. No ano seguinte ao de sua formatura, dirigiu o Colégio Culto à Ciência, que se tornou famoso. Fundou, depois, outro colégio na Ladeira do Porto Geral, passando-o, posteriormente, ao Dr. Ivahy.

Defendeu teses e recebeu o grau de doutor em 1859.

Foi promotor público em 1860 e ocupou, nos biênios de 1864-65 e 1866-67, uma cadeira de deputado provincial.

Como inspetor geral da Instrução Pública, inaugurou, em 2 de agosto de 1880, a Escola Normal de São Paulo.

Por decreto de 5 de setembro de 1882, aprovado em concurso, foi nomeado lente substituto da Faculdade de Direito de São Paulo e, depois de ter feito um concurso anterior, do qual saiu nomeado o Dr. Sá e Benevides, tomou posse aos 13 do mesmo mês. Por decreto de 5 de maio de 1887, foi nomeado lente catedrático de direito civil, primeira cadeira do quarto ano, tendo tomado

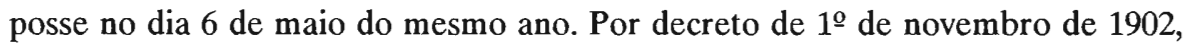
foi nomeado vice-diretor e empossado a 17 do mesmo mês. Por decreto de $7 \mathrm{de}$ dezembro de 1904, foi nomeado diretor, na vaga, por falecimento, do Dr. João Pereira Monteiro. Tomou posse no dia 13 do mesmo mês.

Faleceu aos 9 de agosto de 1908. 